Prepared in cooperation with the Columbia Basin Ground Water Management Area

\title{
Evaluating Regional Trends in Ground-Water Nitrate Concentrations of the Columbia Basin Ground Water Management Area, Washington
}

Scientific Investigations Report 2005-5078 


\section{Evaluating Regional Trends in Ground-Water Nitrate Concentrations of the Columbia Basin Ground Water Management Area, Washington}

By L.M. Frans and D.R. Helsel

Prepared in cooperation with the

Columbia Basin Ground Water Management Area

Scientific Investigations Report 2005-5078 


\section{U.S. Department of the Interior \\ Gale A. Norton, Secretary \\ U.S. Geological Survey \\ Charles G. Groat, Director}

U.S. Geological Survey, Reston, Virginia: 2005

For sale by U.S. Geological Survey, Information Services
Box 25286, Denver Federal Center
Denver, CO 80225
For more information about the USGS and its products:
Telephone: 1-888-ASK-USGS
World Wide Web: http://www.usgs.gov/

\footnotetext{
Any use of trade, product, or firm names in this publication is for descriptive purposes only and does not imply endorsement by the U.S. Government.

Although this report is in the public domain, permission must be secured from the individual copyright owners to reproduce any copyrighted materials contained within this report.

Suggested citation:

Frans, L.M., and Helsel, D.R., 2005, Evaluating regional trends in ground-water nitrate concentrations of the Columbia Basin Ground Water Management Area, Washington: U.S. Geological Survey Scientific Investigations Report 2005-5078, 7 p.
} 


\section{Contents}

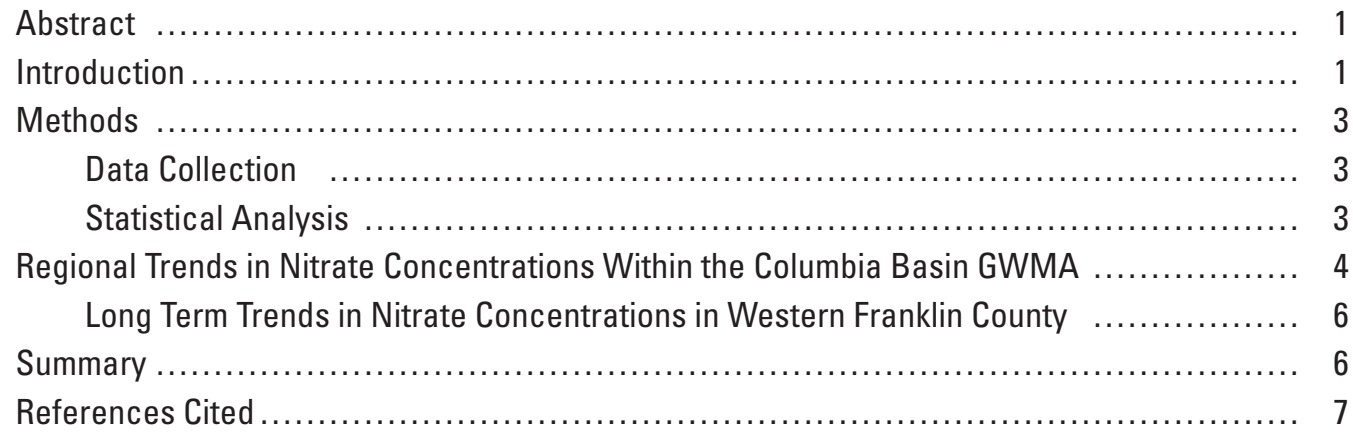

\section{Figures}

Figure 1. Map showing locations of wells sampled for nitrate concentrations in the Columbia Basin Ground Water Management Area, Washington ................. 2

Figure 2. Graph showing LOWESS smooth of nitrate concentrations in ground water during 1998, 2000, 2002, in Adams, Franklin, and Grant Counties, Washington ..... 4

Figure 3. Graph showing LOWESS smooth of nitrate concentrations in ground water by well depth in Adams, Franklin, and Grant Counties, Washington

Figure 4. Graph showing LOWESS smooth of residual nitrate concentrations in ground water during 1998, 2000, and 2002, in Adams, Franklin, and Grant Counties, Washington

Figure 5. Graph showing nitrate concentrations of ground water sampled in the Basin City, Pasco, and East Franklin subregions, 1986 through 2002

\section{Tables}

Table 1. Median concentrations of nitrate and percentage of sampled wells with nitrate concentrations that exceed $10 \mathrm{mg} / \mathrm{L}$, Columbia Basin Ground Water Management Area, Washington, 1998-2002.

Table 2. Summary of results from regional Kendall test for trends in nitrate concentrations in ground water in the Columbia Basin Ground Water Management Area, Washington, 1998-2002.

Table 3. Summary of results of regional Kendall test for trends in nitrate concentrations in ground water in the western portion of Franklin County, Washington, 1986-2003. 


\section{Conversion Factors}

\begin{tabular}{lll}
\hline Multiply & \multicolumn{1}{c}{ By } & To obtain \\
\hline foot $(\mathrm{ft})$ & 0.3048 & meter \\
mile $(\mathrm{mi})$ & 1.609 & kilometer \\
square mile $\left(\mathrm{mi}^{2}\right)$ & 2.590 & square kilometer \\
\hline
\end{tabular}

Concentrations of chemical constituents in water are given in milligrams per liter (mg/L). 


\title{
Evaluating Regional Trends in Ground-Water Nitrate Concentrations of the Columbia Basin Ground Water Management Area, Washington
}

\author{
By L.M. Frans and D.R. Helsel
}

\begin{abstract}
Trends in nitrate concentrations in water from 474 wells in 17 subregions in the Columbia Basin Ground Water Management Area (GWMA) in three counties in eastern Washington were evaluated using a variety of statistical techniques, including the Friedman test and the Kendall test. The Kendall test was modified from its typical 'seasonal' version into a 'regional' version by using well locations in place of seasons. No statistically significant trends in nitrate concentrations were identified in samples from wells in the GWMA, the three counties, or the 17 subregions from 1998 to 2002 when all data were included in the analysis. For wells in which nitrate concentrations were greater than 10 milligrams per liter $(\mathrm{mg} / \mathrm{L})$, however, a significant downward trend of $-0.4 \mathrm{mg} / \mathrm{L}$ per year was observed between 1998 and 2002 for the GWMA as a whole, as well as for Adams County $(-0.35 \mathrm{mg} / \mathrm{L}$ per year) and for Franklin County $(-0.46 \mathrm{mg} / \mathrm{L}$ per year). Trend analysis for a smaller but longer-term 51-well dataset in Franklin County found a statistically significant upward trend in nitrate concentrations of $0.1 \mathrm{mg} / \mathrm{L}$ per year between 1986 and 2003. The largest increase of nitrate concentrations occurred between 1986 and 1991. No statistically significant differences were observed in this dataset between 1998 and 2003 indicating that the increase in nitrate concentrations has leveled off.
\end{abstract}

\section{Introduction}

The Columbia Basin GWMA includes Adams, Franklin, and Grant Counties in eastern Washington, encompassing an area of $5,985 \mathrm{mi}^{2}$ (fig. 1). The Columbia Basin is one of the Nation's top two producers of potatoes and wheat and is a significant producer of apples and many specialty crops. Much of the southeastern part of the GWMA is intensively irrigated with Columbia River water, whereas dryland or ground-waterirrigated farming and rangeland grazing dominate other parts of the GWMA. More than 80 percent of drinking water in the Columbia Basin comes from ground water.

In a recent study of nitrite plus nitrate as nitrogen (hereafter referred to as nitrate) in ground water in Adams, Franklin, and Grant Counties, the concentrations of nitrate in 23 percent of the more than 550 wells that were sampled exceeded the U.S. Environmental Protection Agency maximum contaminant level (MCL) for nitrate in drinking water of $10 \mathrm{mg} / \mathrm{L}$, and concentrations in an additional 37 percent of the wells were between 3 and $10 \mathrm{mg} / \mathrm{L}$ (Ryker and Frans, 2000). Concentrations of nitrate greater than $3 \mathrm{mg} / \mathrm{L}$ are usually indicative of anthropogenic impacts on ground water (Madison and Brunett, 1985). The Columbia Basin GWMA was formed in 1998 with the goal of reducing the concentrations of nitrate in ground water of the area by implementing agricultural best management practices including improving irrigation water management and using nutrient management guidelines for fertilizer use (Columbia Basin GWMA, 2001). As part of the GWMA's ground-water monitoring activities, water samples are collected every 2 years from wells located in 17 sampling subregions (fig. 1), which are defined geographically by soil types, irrigation systems, natural boundaries, and communities. Most of the subregions are dominated by irrigated agricultural lands with the exception of Hartline, Adams dryland, Esquatzel, and Franklin dryland, which are predominately dryland agriculture, and Range, which is predominately rangeland. Additional description of the subregions can be found in Ryker and Frans (2000). The goal of this study is to evaluate changes (trends) of nitrate concentrations in ground water to determine if the GWMA is meeting its goal of reducing nitrate concentrations. 


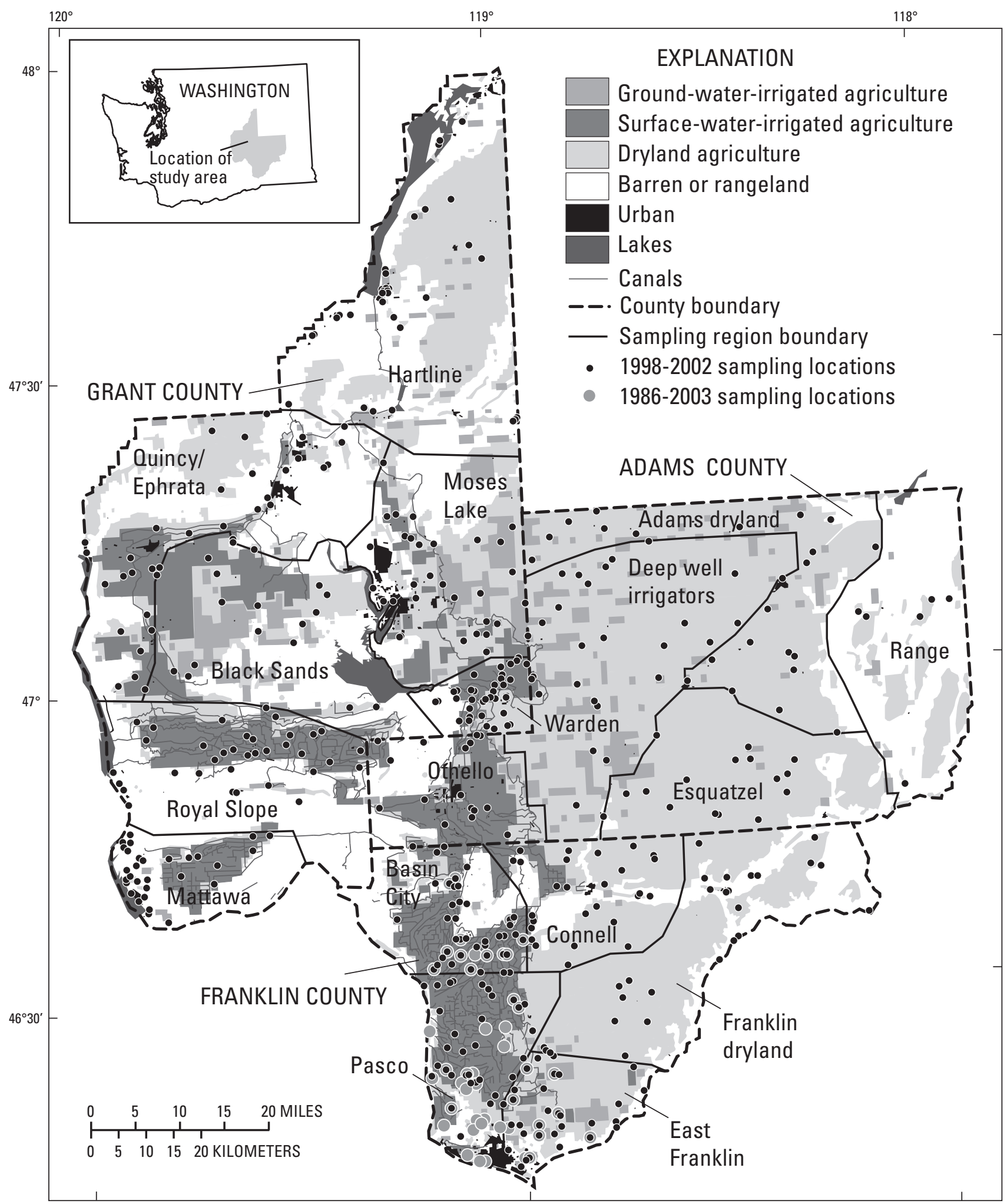

Figure 1. Locations of wells sampled for nitrate concentrations in the Columbia Basin Ground Water Management Area, Washington. 


\section{Methods}

\section{Data Collection}

Two datasets were used to examine trends of nitrate concentrations in the Columbia Basin GWMA. As part of the GWMA's monitoring activities, water samples were collected in 1998, 2000, and 2002 from the same 474 wells in the 17 sampling regions (fig. 1) (Ryker and Frans, 2000). The samples were analyzed for nitrate at the Washington State Department of Ecology Manchester Laboratory using a cadmium-reduction analytical method. A second dataset contains nitrate concentrations in water from 51 wells in Franklin County that were sampled in 1986, 1991, 1995, 1998, and 2003. All of these samples were analyzed at a contract laboratory using an ion-selective electrode analytical method, except those collected in 1986, which were analyzed at the U.S. Geological Survey National Water Quality Laboratory using a cadmium-reduction method. A review of replicate and reference solution samples analyzed by both methods indicated that the nitrate concentrations determined using the ion-selective electrode method resulted in increasingly under-reported values as the concentrations increased (negative bias). Therefore, linear relations between the nitrate concentrations determined by the two methods were used to adjust the concentrations determined by the ion-selective electrode method to be compatible with those determined by the cadmium-reduction method. The linear relations are quite strong as indicated by the high $R^{2}$ values of 0.998 for the 1991-98 data and 0.990 for the 2003 data.

\section{Statistical Analysis}

Statistical analytical methods can be divided into two general classes, parametric and nonparametric. Parametric methods use parameters of the data, usually the mean and standard deviation, to summarize the information contained in the data. This summary is valid only when the data fit the distribution (usually a normal distribution) assumed by the method; otherwise the method may result in misleading conclusions and will not be very robust in detecting differences or trends. Water-quality data are usually skewed so that the concentrations do not follow a normal distribution. Therefore, nonparametric tests, which do not assume that the data follow any specific distribution, were used in this analysis. Nonparametric tests have greater power to detect differences or trends than do parametric methods when the data do not follow a normal distribution.

Prior to conducting statistical tests for trends, LOWESS smooth plots of the data were prepared to visually check for trends. LOWESS (Helsel and Hirsch, 2002), which stands for "locally-weighted scatterplot smoothing," is a weighted least-squares method of placing a curve through the center of the data for the dependant variable. The curve will follow the shape and direction of the data as they progress along the $x$-axis, forming a straight line when the data progress in a linear manner and a curve when they do not. The resulting smooth defines the central tendency of the data. The most beneficial use of this method is on a graph to emphasize the shape of the relation between the two variables for one or more groups of data. As with many other types of smoothing methods, there is no single equation that defines a LOWESS smooth because it changes as you move a long a line. LOWESS smooths were used in this study to display the central tendency of several groups of data on the same plot.

The sign test determines whether the medians of two groups are equal, when those groups are composed of observations paired by some auxillary variable (Conover, 1999). For environmental data, pairs are often composed of observations taken at the same place. By pairing observations, influences on the data other than the one being investigated can be compensated for and blocked out. The sign test determines whether the second observation in a pair (the 'ending point') shows an increase or decrease from its paired observation at the 'starting point'. In this study, the data were paired by location, and concentrations tested to see if they were consistently higher in the later time period than in the earlier period.

The Friedman test (Conover, 1999) extends the sign test to more than two sets of related observations. The pattern of increases or decreases within sets of three or more related observations is evaluated to see if it is consistent across many sets. The Friedman test has two explanatory variables, one on the rows and the other on the columns. The row effects are 'removed' or 'blocked out' when ranking is done within a row. No comparisons are made between data in different rows. In this study, observations at the same location (the 'rows') were compared among years (the 'columns') to determine if there was a consistent increase or decrease over time.

The seasonal Kendall test is one of the most commonly used tests for trend in environmental science (Helsel and Hirsch, 2002). The test counts the numbers of sequential increases and decreases in concentration across multiple years of data, conducting the test individually within each season and then combining the results into one overall test for trend. The test may be run directly on the concentration data, or on data adjusted by first taking the residuals from a LOWESS smooth of concentration versus an auxillary variable. By using residuals, the dependence between concentration and the auxillary variable is subtracted out, thus removing noise unrelated to time trend from the test for trend. In this study, the dependence of the concentration of nitrate on the depth of each well was subtracted out prior to conducting the test (as discussed in more detail in the following section), so that differences in concentration resulting only from differences in depth are accounted for. 
One difference between the implementation of the seasonal Kendall test used in this study and its usual form is that individual well locations were used instead of seasons of the year as the "season" variable. Trend tests were conducted at each individual well location and Kendall's S statistic for each well was then summed with others from the same region, so that the overall test determined if there was a consistent regional trend throughout the entire county or management area. In this implementation, the test acts as a "regional Kendall test for trend."

The statistical analyses performed for this study were considered significant at a $p$-value of less than or equal to 0.05 and moderately significant at a $p$-value of less than or equal to 0.1 .

\section{Regional Trends in Nitrate Concentrations Within the Columbia Basin GWMA}

The distribution of nitrate concentrations for Adams, Franklin, and Grant Counties are very similar to one another from 1998 to 2002 (fig. 2). The LOWESS smooth shows that Franklin County generally had the highest nitrate concentrations and that the concentrations appear to be fairly consistent during this time period. The LOWESS smooth shows that Grant and Adams Counties may have an overall decrease in concentrations over this time period. This general pattern of decreasing concentrations also is shown in the summary statistics that were computed for each county and sampling region in the GWMA to compare changes in the median concentrations and the percentages of wells with concentrations exceeding the MCL (table 1). The median nitrate concentration has changed little between 1998 and 2002 for the GWMA as a whole, decreasing from 4.07 to $3.95 \mathrm{mg} / \mathrm{L}$ during 2000, and then increasing to $4.04 \mathrm{mg} / \mathrm{L}$ during 2002 . Individual counties and sampling regions showed more variability in changes in median concentrations, but typically varied by less than $1 \mathrm{mg} / \mathrm{L}$. The median concentrations of nitrate in all three counties in 2002 were lower than or equal to the median concentrations in 1998, and in all but four of the sampling regions, median concentrations were lower in 2002 than in 1998. Additionally, the percentage of all wells in which the MCL of $10 \mathrm{mg} / \mathrm{L}$ nitrate was exceeded decreased from 20.9 percent during 1998 to 18.6 percent during 2002. Each of the three counties also showed a decrease in the percentage of wells with nitrate concentrations above the MCL, with Adams County having the largest decrease from 19.3 percent to 12.5 percent. The question, then, is whether this apparent pattern of generally decreasing concentrations between 1998 and 2002 is statistically significant.

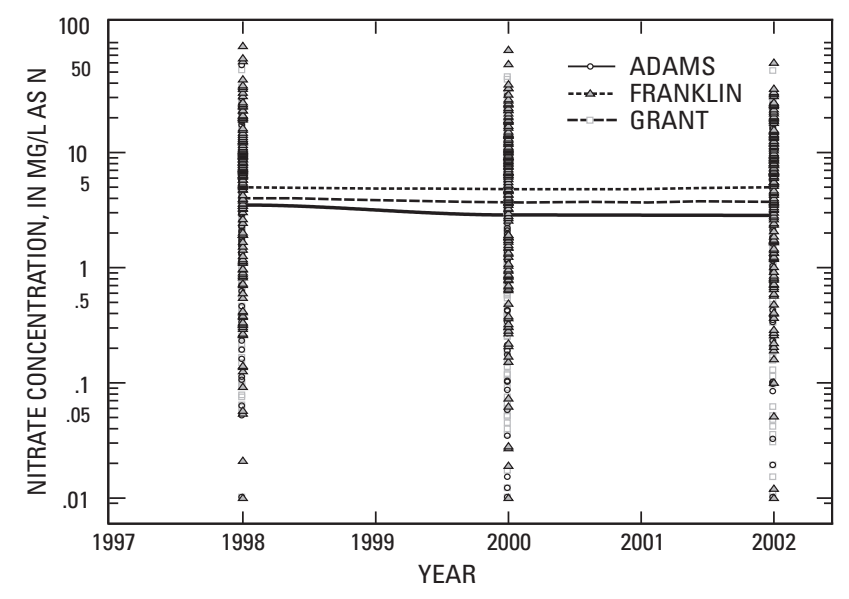

Figure 2. LOWESS smooth of nitrate concentrations in ground water during 1998, 2000, 2002, in Adams, Franklin, and Grant Counties, Washington.

Table 1. Median concentrations of nitrate and percentage of sampled wells with nitrate concentrations that exceed $10 \mathrm{mg} / \mathrm{L}$, Columbia Basin Ground Water Management Area, Washington, 1998-2002.

[Abbreviations: mg/L, milligram per liter; GWMA, Ground Water Management Area]

\begin{tabular}{|c|c|c|c|c|c|c|}
\hline \multirow[t]{2}{*}{ Area } & \multicolumn{3}{|c|}{ Median } & \multicolumn{3}{|c|}{$\begin{array}{l}\text { Percentage of wells with } \\
\text { nitrate concentrations } \\
\text { that exceed } 10 \mathrm{mg} / \mathrm{L}\end{array}$} \\
\hline & 1998 & 2000 & 2002 & 1998 & 2000 & 2002 \\
\hline GWMA & 4.07 & 3.95 & 4.04 & 20.9 & 19.4 & 18.6 \\
\hline Adams County & 3.27 & 2.95 & 2.82 & 19.3 & 13.6 & 12.5 \\
\hline Adams dryland & 5.46 & 4.78 & 3.29 & 30.4 & 26.1 & 17.4 \\
\hline Deep well irrigators & 1.29 & 1.47 & 1.23 & 18.5 & 7.4 & 7.4 \\
\hline Esquatzel & 4.39 & 2.72 & 6.19 & 20.0 & 20.0 & 26.7 \\
\hline Othello & 4.75 & 1.83 & 2.81 & 11.1 & 5.6 & 5.6 \\
\hline Range & 2.91 & 3.22 & 2.77 & 0.0 & 0.0 & 0.0 \\
\hline Franklin County & 5.80 & 5.06 & 5.54 & 27.5 & 27.5 & 26.9 \\
\hline Basin City & 7.60 & 6.78 & 6.79 & 40.0 & 42.5 & 35.0 \\
\hline Connell & 1.92 & 1.88 & 2.39 & 3.6 & 0.0 & 7.1 \\
\hline East Franklin & 7.29 & 8.01 & 7.24 & 42.4 & 48.5 & 45.5 \\
\hline Franklin dryland & 1.15 & 1.18 & 1.28 & 7.7 & 7.7 & 3.8 \\
\hline Pasco & 8.16 & 7.51 & 8.01 & 33.3 & 27.3 & 33.3 \\
\hline Grant County & 3.94 & 3.85 & 3.94 & 16.9 & 16.0 & 15.1 \\
\hline Black Sands & 6.53 & 6.61 & 6.50 & 29.4 & 35.3 & 35.3 \\
\hline Hartline & 2.60 & 2.15 & 4.18 & 23.5 & 23.5 & 17.6 \\
\hline Mattawa & 1.86 & 1.50 & 1.54 & 12.1 & 9.1 & 9.1 \\
\hline Moses Lake & 3.29 & 2.59 & 2.58 & 15.6 & 15.6 & 9.4 \\
\hline Quincy/Ephrata & 3.91 & 3.72 & 3.80 & 5.3 & 5.3 & 7.9 \\
\hline Royal Slope & 5.96 & 5.61 & 5.70 & 16.7 & 16.7 & 16.7 \\
\hline Warden & 5.46 & 4.39 & 4.82 & 22.9 & 17.1 & 20.0 \\
\hline
\end{tabular}


The Friedman test was used to determine whether the sets of nitrate concentration data for the GWMA as a whole were significantly different in each year. If they were not significantly different, there could be no trend. The Friedman test indicated that the nitrate concentrations were significantly different among the three sampling periods ( $p$-value $=0.002$ ). It is possible, however, for the nitrate concentrations to be significantly different from each other but still not be indicative of a trend if the differences do not occur in a consistent direction. In this case, the median concentration decreased from 1998 to 2000 before increasing during 2002, indicating that there may not be an overall trend.

Prior to testing the nitrate concentrations for trends using the Regional Kendall test, the effect of depth on the concentrations was first subtracted out using a LOWESS smooth line. As can be seen in figure 3, concentrations generally decrease with increasing depth, although concentrations for Franklin and Grant Counties increase slightly with increasing depth up to about 200 feet. By using residuals from the LOWESS smooth line of the nitrate concentrations, all wells are placed on an equal footing regardless of their depth. After adjusting for depth, it appears that Franklin County concentrations remain relatively flat, whereas concentrations for Adams and Grant Counties show a slight decline, particularly between 1998 and 2000 (fig. 4). However, despite the graphical indication of a possible downward trend, the Regional Kendall test for trend indicated that there were no statistically significant trends in the GWMA as a whole, in the three counties, nor in any of the 17 sampling regions (table 2). The GWMA as a whole did have a moderately significant downward trend with a $p$-value of 0.09 and a rate of change of $-0.002 \mathrm{mg} / \mathrm{L}$ per year.

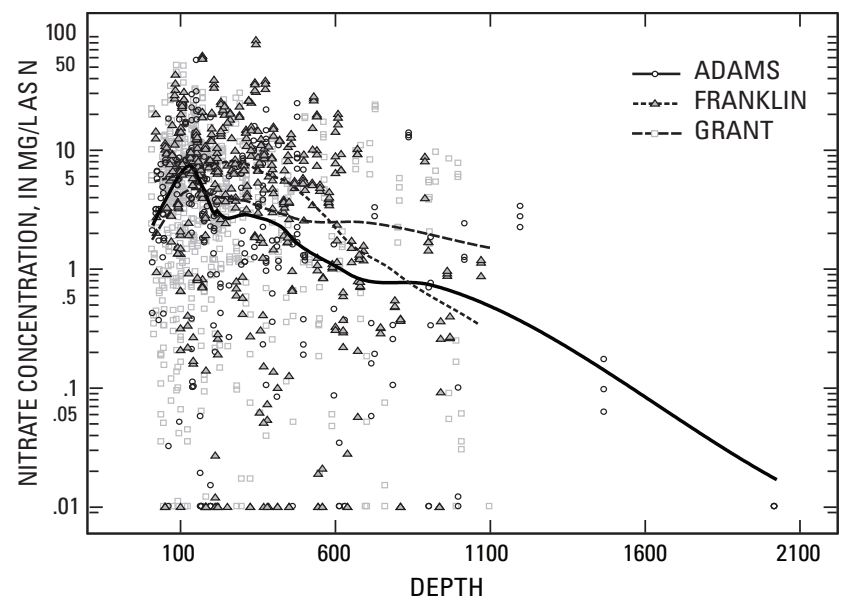

Figure 3. LOWESS smooth of nitrate concentrations in ground water by well depth in Adams, Franklin, and Grant Counties, Washington.

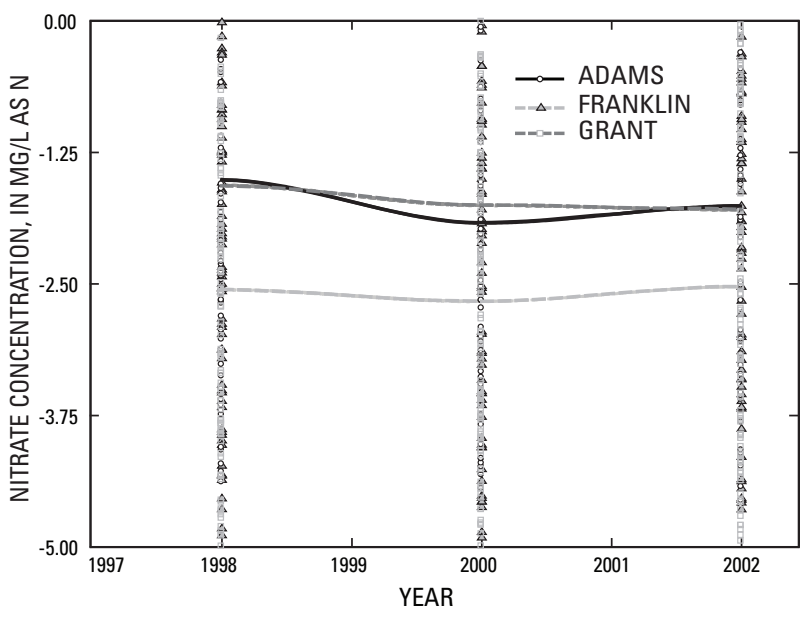

Figure 4. LOWESS smooth of residual nitrate concentrations in ground water during 1998, 2000, and 2002, in Adams, Franklin, and Grant Counties, Washington. (Data points extend above zero, but the y-axis was truncated to adequately show shape of LOWESS curve.)

Table 2. Summary of results from regional Kendall test for trends in nitrate concentrations in ground water in the Columbia Basin Ground Water Management Area, Washington, 1998-2002.

[Abbreviations: mg/L, milligram per liter; GWMA, Ground Water Management Area]

\begin{tabular}{lccc}
\hline \multicolumn{1}{c}{ Area } & $\begin{array}{c}\text { Kendall's } \\
\text { Tau }\end{array}$ & P-value & $\begin{array}{c}\text { Rate of change } \\
\text { (mg/L per year) }\end{array}$ \\
\hline GWMA & -0.05 & 0.09 & -0.002 \\
Adams County & -0.014 & 0.72 & -0.018 \\
Adams dryland & -0.066 & 0.39 & -0.070 \\
Deep well irrigators & 0.029 & 0.69 & 0.044 \\
Esquatzel & 0.017 & 0.87 & 0.025 \\
Othello & -0.040 & 0.66 & -0.036 \\
Range & -0.048 & 0.83 & -0.073 \\
Franklin County & 0.004 & 0.89 & 0.004 \\
Basin City & -0.041 & 0.49 & -0.042 \\
Connell & 0.073 & 0.31 & 0.052 \\
East Franklin & 0.007 & 0.91 & 0.008 \\
Franklin dryland & 0.025 & 0.73 & 0.025 \\
Pasco & 0.0 & 1.0 & 0.0 \\
Grant County & -0.015 & 0.52 & -0.02 \\
Black Sands & -0.007 & 0.94 & -0.008 \\
Hartline & -0.008 & 0.90 & -0.015 \\
Mattawa & 0.0 & 1.0 & 0.0 \\
Moses Lake & -0.03 & 0.60 & -0.046 \\
Quincy/Ephrata & -0.022 & 0.72 & -0.018 \\
Royal Slope & -0.024 & 0.70 & -0.027 \\
Warden & -0.031 & 0.62 & -0.032 \\
\hline
\end{tabular}


An additional trend analysis for the GWMA as a whole was conducted for those wells that had a starting nitrate concentration exceeding the MCL of $10 \mathrm{mg} / \mathrm{L}$. For these 99 wells, there was a statistically significant downward trend ( $p$-value $<0.0001$ ) in concentrations between 1998 and 2002, with a rate of change of $-0.4 \mathrm{mg} / \mathrm{L}$ per year. A downward trend within this group of wells is especially important because it indicates that the particularly high nitrate concentrations in the GWMA, which are most likely to affect human health, are beginning to decrease. Adams and Franklin Counties also showed significant downward trends for these high-nitrate wells of $-0.35 \mathrm{mg} / \mathrm{L}$ per year $(p$-value $=0.042)$ and $-0.46 \mathrm{mg} / \mathrm{L}$ per year ( $p$-value $<0.0001)$, respectively. However, concentrations in wells in Grant County did not show a statistically significant trend $(p$-value $=0.17)$.

\section{Long Term Trends in Nitrate Concentrations in Western Franklin County}

The LOWESS smooth for the longer term 51-well dataset, which includes the Basin City, Pasco, and East Franklin subregions, indicates that concentrations of nitrate in ground water in western Franklin County generally have increased since 1986 but have leveled off since about 1995 (fig. 5). The flattening of the LOWESS smooth line during the later years mirrors that of the Franklin County wells in the larger dataset for the same time period (fig. 2).

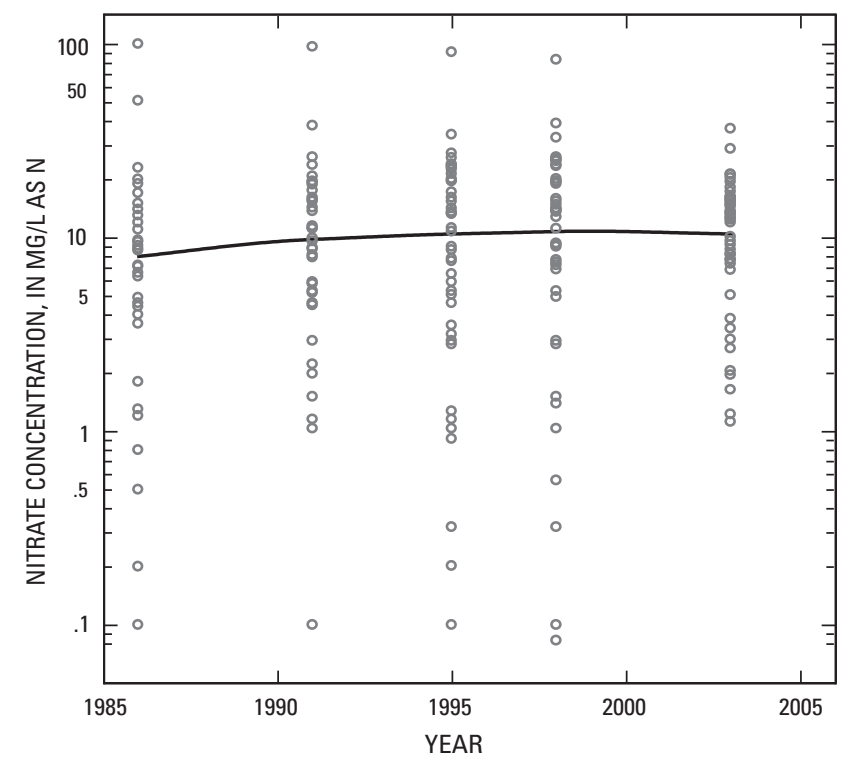

Figure 5. Nitrate concentrations of ground water sampled in the Basin City, Pasco, and East Franklin subregions, 1986 through 2002.
The Friedman test indicates that there are statistically significant differences in nitrate concentrations among the five sampling periods ( $p$-value $<0.0001)$. However, unlike the GWMA as a whole, the median rose in each subsequent sampling period, indicating a consistent increase in nitrate concentrations over time.

The regional Kendall test for trend indicates that this pattern of rising nitrate concentrations is statistically significant ( $p$-value $<0.0001$ ) for the 51-well dataset as a whole, with a rate of change of $0.1 \mathrm{mg} / \mathrm{L}$ per year between 1986 and 2003 (table 3). When broken down by the three sampling regions, however, there was no statistically significant trend within an individual region ( $p$-values ranged from 0.13 for East Franklin to 0.87 for Basin City). The increasing trend for the dataset as a whole is driven by the increases in the early years. The sign test indicated there was strong evidence for a trend between 1986 and 1991 ( $p$-value $=0.007)$ whereas there was no evidence of an increase in concentrations between 1998 and 2003 ( $p$-value $=0.78)$. The leveling off of the nitrate concentrations in the later sampling periods mirrors the lack of a trend in the larger GWMA dataset as a whole, and also in the three sampling regions that are represented in both datasets.

Table 3. Summary of results of regional Kendall test for trends in nitrate concentrations in ground water in the western portion of Franklin County, Washington, 1986-2003.

[Abbreviation: mg/L, milligram per liter]

\begin{tabular}{lccc}
\hline \multicolumn{1}{c}{ Area } & $\begin{array}{c}\text { Kendall's } \\
\text { Tau }\end{array}$ & P-value & $\begin{array}{c}\text { Rate of change } \\
\text { (mg/L per year) }\end{array}$ \\
\hline Franklin County & 0.257 & $<0.0001$ & 0.1 \\
Basin City & 0.014 & 0.87 & 0.0 \\
East Franklin & 0.132 & 0.13 & 0.21 \\
Pasco & 0.067 & 0.25 & 0.10 \\
\hline
\end{tabular}

\section{Summary}

Regional trends in nitrate concentrations in groundwater samples collected from 474 wells in the Columbia Basin GWMA in 1998, 2000, and 2002 were estimated using a variety of statistical techniques including LOWESS smoothing, the Friedman test, and the Kendall test. The Kendall test was modified from its typical 'seasonal' version into a 'regional' version by replacing the season variable with individual well locations. 
A comparison of the median concentrations and the percentages of wells with nitrate concentrations exceeding the drinking-water MCL of 10 milligram per liter (mg/L) for each of the three years indicated that the nitrate concentrations may have decreased slightly between 1998 and 2002. This indication of a slight decrease also was supported by the LOWESS smooth graphs. The Friedman test indicated statistically significant differences among the three years, but those differences may not necessarily occur in a consistent direction. The Regional Kendall test indicated no statistically significant trends in nitrate concentrations in the GWMA, the three counties encompassed by the GWMA, or the 17 sampling regions from 1998 to 2002 . However, a significant downward trend of $-0.4 \mathrm{mg} / \mathrm{L}$ per year was found between 1998 and 2002 for all GWMA wells that had nitrate concentrations exceeding $10 \mathrm{mg} / \mathrm{L}$. Significant downward trends of -0.35 and $-0.46 \mathrm{mg} / \mathrm{L}$ per year also were found in wells with starting nitrate concentrations exceeding $10 \mathrm{mg} / \mathrm{L}$ for Adams and Franklin Counties, respectively. Concentrations in wells in Grant County with a starting concentration (in 1998) exceeding $10 \mathrm{mg} / \mathrm{L}$ did not show a significant trend.

Trend analysis for a smaller 51-well dataset from Franklin County found a statistically significant upward trend in concentrations of nitrate of $0.1 \mathrm{mg} / \mathrm{L}$ per year between 1986 and 2003. This indicated increase in concentrations was driven primarily by changes in concentration between 1986 and 1991. No significant differences were found between 1998 and 2003, indicating that the increase in nitrate concentrations has leveled off, which mirrors the lack of a significant overall trend in the larger dataset.

\section{References Cited}

Columbia Basin GWMA, 2001, The Columbia Basin GWMA plan: accessed August 6, 2004 at http://www.gwma.org/ plan.htm.

Conover, W.J., 1999, Practical nonparametric statistics, 3rd ed.: New York: John Wiley and Sons, 583 p.

Helsel, D. R., and Hirsch, R.M., 2002, Statistical methods in water resources: U.S. Geological Survey Techniques of Water-Resources Investigations, Book 4, Chapter A3, accessed March 2004 at http://water.usgs.gov/pubs/twri/ twri4a3/.

Madison, R.J., and Brunett, J.O., 1985, Overview of the occurrence of nitrate in ground water of the United States in U.S. Geological Survey, National Water Summary Hydrologic events, selected water-quality trends, and ground-water resources: U.S. Geological Survey WaterSupply Paper 2275, p. 93-105.

Ryker, S.J., and Frans, L.M., 2000, Summary of nitrate concentrations in ground water of Adams, Franklin, and Grant Counties, Washington, fall 1998—A baseline for future trend analysis: U.S. Geological Survey WaterResources Investigations Report 99-4288. 
Manuscript approved for publication, September 17, 2004

Prepared by the Publishing Group, U.S. Geological Survey, Washington Water Science Center, Tacoma, Washington

USGS Publishing staff

Debbie Grillo

Bill Gibbs

Bob Crist

Linda Rogers

Bobbie Jo Richey

For more information concerning the research in this report, contact the Washington Water Science Center Director,

U.S. Geological Survey, 1201 Pacific Avenue - Suite 600

Tacoma, Washington 98402

http://wa.water.usgs.gov 


\section{$\mathbb{1}$ 总}

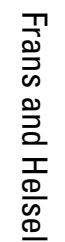

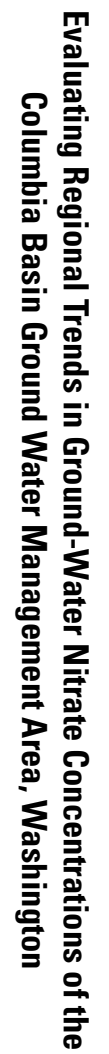

